\title{
Prevalence of Vibrio alginolyticus in Sediment Samples of River and Coastal Areas of Bangladesh
}

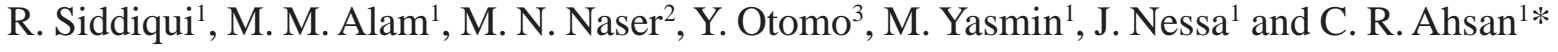 \\ ${ }^{1}$ Department of Microbiology, University of Dhaka, Dhaka, Bangladesh, ${ }^{2}$ Department of Zoology, University of Dhaka, Dhaka, Bangladesh, ${ }^{3}$ Division of Medical \\ Life Sciences, Hirosaki University, Aomori, Japan
}

\begin{abstract}
Vibrio alginolyticus has been thought to be a halophilic marine bacterium that causes diarrhea, otitis media and wound infection through the consumption of raw or inappropriately cooked sea food. It is one of the main Vibrio pathogens affecting marine animals, such as marine fish, shrimp and shellfish which lead to large economic damage. Although there are reports on the presence of this organism in the coastal area of other countries, not so much work has been done on the isolation and characterization of this species in Bangladesh. The present study was, therefore, undertaken to isolate and characterize $V$. alginolyticus organisms isolated from the rivers (fresh water) and estuaries (brackish water) of Bangladesh. A total of 9 isolates of Vibrio species were obtained from different water bodies (three from Meghna river, two from Shangu river and four from estuary) and provisionally identified as Vibrio alginolyticus following standard biochemical tests. All these $\mathbf{9}$ strains showed same pattern of antibiotic resistance to ampicillin, streotomycin, penicillin, but sensitive to nalidixic acid. In the virulence properties test, two isolates showed positive results for tox $R$ gene and none of the isolates showed positive results for $t d h$ gene. Challenge experiments in Singhi fish (Heteropneustes fossi) with the live cells and the culture filtrate prepared from the $V$. alginolyticus showed high mortality of the fish population. All these studies suggest the presence of pathogenic $V$. alginolyticus strains in the river water and estuarine bodies of Bangladesh and the extracellular toxin(s) of the $V$. alginolyticus might be one of the causes for fish mortality.
\end{abstract}

Keywords: Vibrio alginolyticus, toxR gene, trh gene, tdh gene

\section{Introduction}

Vibrio alginolyticus is a Gram negative bacterium belonging to the family vibrioceae that cause cholera. It is a moderately halophile or salt requiring organism that lives in marine and estuarine environments ${ }^{\mathbf{1}}$. It causes gastrointestinal illness in humans after ingestion of contaminated sea water and sea foods ${ }^{2}$. Moreover, V. alginolyticus is able to cause extraintestinal diseases, such as otitis media and wound infection to human $^{3}$ and it is an epizootic pathogen to several aquatic animals $^{4,5}$. In South China, V. alginolyticus has been reported to be the dominant causative agent of high mortality outbreaks of vibriosis in large yellow croaker, sea bream, grouper, kuruma prawn as well as in larvae of several fish and shellfish species ${ }^{6}$, ${ }^{7}$. This organism persists as a health hazard in the Far East, where it was originally isolated $\mathbf{8}^{\mathbf{8}}$ and also as a source of human disease or as an environmental contaminant along the North American, African, and Mediterranean coasts ${ }^{9,10,11}$. This bacterium causes approximately half of all food poisoning cases in Taiwan, Japan and several Southeast Asian countries ${ }^{2,12}$. Strains of $V$. alginolyticus are among the most common organisms isolated from diseased fish with clinical signs of bacterial septicemia ${ }^{13,14}$. $V$. alginolyticus has also been reported to be responsible for ulcer disease of the gilthead seabream, sparus aurata, turbot, crimson snapper and sea mullet ${ }^{15}$.

$V$. alginolyticus was originally classified as a biotype of $V$. parahemolyticus, the two of which are genetically quite similar. They can be differentiated phenotypically on the basis of fermentation of sucrose by $V$. alginolyticus ${ }^{2}$. Some differences in taxonomic traits between clinical and environmental isolates of $V$. alginolyticus have also been suggested. Several virulence factors, including iron uptake system, extracellular polysaccharide and protease have been suggested to be the major contributors to pathogenicity in this species ${ }^{3,4,7}$. However, there are not much reports on the pathogenicity of the $V$. alginolyticus isolated from different sources in and around estuaries. Therefore, this work was undertaken to investigate the occurrence of $V$. alginolyticus in the estuaries as well as rivers in Bangladesh and to compare the phenotypic and genotypic traits, as well as the pathogenicity of these organisms.

\section{Materials and Methods}

Sample collection and processing

Sediment samples were collected from June to September, 2008 from three coastal area (Estuary, Shangu and Karnaphuli) and 
six rivers (Buriganga at Dhaka, Shitalakhya at Narayanganj, Turag at Dhaka, Padma at Rajshshi, Jamuna at Shirajganj, Meghna at Comilla, and Padma at Maoa) of Bangladesh.

Sediment samples were collected from $10 \mathrm{~cm}$ depth of the shore by the help of sterile scoop. Approximately 100 grams of samples were aseptically collected in sterile plastic bags. Samples were stored at room temperature until processing in the laboratory. The salinity of the sample was measured in the laboratory by a refractometer.

Alkaline peptone water (APW) was used to facilitate the growth of Vibrio spp. One gram of sediment sample was mixed with 9 $\mathrm{ml}$ of APW supplemented with $2 \% \mathrm{NaCl}$ and incubated at $37{ }^{\circ} \mathrm{C}$ for $6 \mathrm{~h}$. After incubation, the enriched culture was shaken and one loopful of the culture was streaked on to X-VP media (XVP agar; Nissui Co. Japan).

\section{Screening of suspected $V$. alginolyticus colonies}

White colonies on X-VP agar plates were selected as suspected $V$. alginolyticus after overnight incubation at $37^{\circ} \mathrm{C}$. Five to ten suspected $V$. alginolyticus colonies were picked up and subcultured onto fresh X-VP plate for pure culture. Again suspected $V$. alginolyticus isolates were streaked onto thiosulphate citrate bile salt sucrose agar (TCBS agar; Nissui Co., Japan). Following overnight incubation at $37^{\circ} \mathrm{C}$, isolates those produced mucoid, raised, yellow, 2-3 mm colonies were selected as $V$. alginolyticus and were readily transferred to Luria- Berrtani (LB) agar containing 3\% NaCl.

\section{Biochemical characterization}

Biochemical tests were performed following standard methods ${ }^{16}$. Kligler's iron agar, lysine decarboxylase, arginine dihydrolase, ornithine decarboxylase, oxidase, citrate utilization, motility, indole production, methyl-red, Vogesproskauer, nitrate reduction, swarming motility and salt tolerance tests were used for the biochemical characterization of $V$. alginolyticus. In addition growth at $40^{\circ} \mathrm{C}$ was also examined.

\section{Antibiotic susceptibility test}

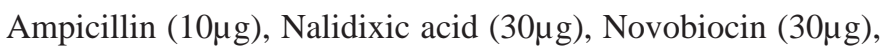

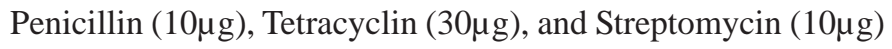
antibiotics were used against all 9 environmental isolates according to the modified Kirby-Bauer method ${ }^{17}$.

\section{Determination of hemolysis activity}

$V$. alginolyticus isolates were screened for hemolysis on sheep blood agar plate followed by incubation at $37^{\circ} \mathrm{C}$ for $18 \mathrm{~h}$.

\section{PCR amplification of the tox $\mathrm{R}$ and tdh gene}

Stock cultures of $V$. alginolyticus were maintained in liquid preservation medium ( $\mathrm{pH}$ 8.8) containing 0.5\% APW and 2.5\% $\mathrm{NaCl}$ and revived on the LB agar plates. A single luminescent colony of each culture was inoculated in tryptic soy broth with $1 \% \mathrm{NaCl}$ and incubated overnight at $37^{\circ} \mathrm{C}$. Genomic DNA was extracted and purified according to GuSCN DNA extraction method $^{18}$. Briefly, 2-3 colonies of the bacteria were picked and suspended in $200 \mu \mathrm{l}$ PBS, centrifuged at $13000 \mathrm{rpm}$ for $5 \mathrm{~min}$. The pellet was resuspended in $200 \mu \mathrm{l}$ of TE buffer containing 1 $\mathrm{mg} / \mathrm{ml}$ lysozyme and $1 \mathrm{mg} / \mathrm{ml}$ acromopeptidase and incubated at $37^{\circ} \mathrm{C}$ for $1 \mathrm{hr}$. After incubation, $300 \mu \mathrm{l}$ of $4 \mathrm{M}$ GuSCN (containing 2\% w/v Tween-20) was added, mixed well and centrifuged at $13000 \mathrm{rpm}$ for $5 \mathrm{~min}$. The supernatant containing the DNA was purified using isopropanol and were its concentration and purity were checked using a spectrophotometer at 260/280 nm (Shimadzu 1601, Kyoto, Japan) and was finally stored at " $20^{\circ} \mathrm{C}$ until further use.

Isolates of $V$. alginolyticus strains used in this study were tested based on PCR targeting the tox R and $t d h$. PCR primers were used for targeting a 399 bp toxR (TOXR-1:AGCCCGC TTTCTTCAGACTC and TOXR-2:AACGAGTCTTC TGCATGGTG) and 251 bp $t d h$ (TDH-3:CCACTACCACTC TCATATGC and TDH-4: GGTACTAAAT GGCTGACATC). PCR was carried out in a $25 \mu \mathrm{L}$ reaction mixture consisting of $2.50 \mu \mathrm{L}$ Taq universal 10X buffer (100 mM Tris- $\mathrm{HCl} \mathrm{pH}$ 8.3, $20 \mathrm{mM}$ MgCl2, $500 \mathrm{mM} \mathrm{KCl,} \mathrm{0.1 \%} \mathrm{gelatin),} 2 \mu \mathrm{L}$ of dNTPs (2.5 mM of each), $0.5 \mu \mathrm{L}$ of each primer (25 pmol of each), $0.125 \mu \mathrm{L}$ of Taq polymerase (0.75 U of Taq polymerase), 17.375 ì sterile deionised water and $2 \mu \mathrm{L}$ of template DNA. Amplification was performed using a thermo cycler system (MJ Research, Watertown, USA) for 5 minutes at $95^{\circ} \mathrm{C}, 35$ cycles of 1 minute at $95{ }^{\circ} \mathrm{C}, 1$ minute at $55^{\circ} \mathrm{C}$, and 1 minute at $72{ }^{\circ} \mathrm{C}$. The PCR products were resolved on $2 \%$ agarose gels containing $0.5 \mu \mathrm{g} /$ $\mathrm{mL}$ ethidium bromide and documented using a gel documentation system (Bio-RAD, USA).

\section{Preparation of live cells as inoculum}

V. alginolyticus cells were incubated in Luria Bertani (LB) broth with $2 \% \mathrm{NaCl}$ for $18 \mathrm{~h}$ on a rotary shaker at $37{ }^{\circ} \mathrm{C}$ and after incubation the density of cells were $\sim 3 \times 10^{8} \mathrm{cfu} / \mathrm{ml}$ which was determined by comparing with that of McFarland standards.

\section{Preparation of culture filtrates as inoculum}

V. alginolyticus cells were grown in $100 \mathrm{ml}$ Brain Heart Infusion (BHI) broth for about 22 hours and the cells were harvested by centrifugation at $6000 \mathrm{rpm}$ for 5 mins. The supernatant was filtered through a $0.45 \mu \mathrm{m}$ syringe filter and kept at $-20^{\circ} \mathrm{C}$.

Challenge of $V$. alginolyticus against Heteropneustes fossi One hundred sixty Singhi fish (Heteropneustes fossi) of 10 to 18 gm body weight and 10 to $15 \mathrm{~cm}$ length were kept for two days in the environment of aquarium for adaptation. 160 fish were equally distributed randomly in 16 aquariums (12-16 litre each). One aquarium was maintained as control and three each of the aquariums were inoculated with $10 \mathrm{ml}$ volume of three different dilutions ( $\sim 10^{4}$ to $\left.10^{6} \mathrm{cfu} / \mathrm{ml}\right)$ of two different $\mathrm{V}$. alginolyticus organisms (M3 isolated from river and E5 isolated from estuary). After five days, two fish from each aquarium (marked as smaller) were transferred to new corresponding 
aquariums containing healthy fish (marked as longer). At least two fish from each aquarium were taken out from each aquarium on day 5 (or any fish which died due to infection) and were checked for the presence of $V$. alginolyticus in different organs of the fish (skin, lung and intestine). Fish in two aquariums were inoculated intra-peritoneally with live $V$. alginolyticus organisms (M3 and E5 series, $100 \mu \mathrm{l}, 10^{5} \mathrm{cfu} / \mathrm{ml}$ ) and observed for 14 days after bacterial inoculation. On the other hand, fish of another aquarium were injected intra-peritoneally with culture filtrate $(0.5 \mathrm{ml})$ prepared from the $V$. alginolyticus. All fish in different aquariums were observed for 14 days.

\section{Results}

\section{Isolation of $V$. alginolyticus}

Twenty five isolated strains were selected as suspected $V$. alginolyticus through enrichment of sample and by primary screening on X-VP (a special medium for Vibrio where $V$. alginolyticus showed characteristic white colored colonies) from 7 different sampling sites (Table 1) viz isolates numbers
8,3,4,1,4,3 and 4, from estuary (Chittagong), Karnaphuli (Chittagong), Shangu (Chittagong), Turag (Dhaka), Sitalakhaya (Dhaka), Padma (Maoa), and Meghna (Comilla) respectively. Salinity (\%) was recorded 0.9, 0.1 and 0.1 in samples collected from estuary, Karnaphuli and Shangu respectively. The suspected V. alginolyticus colonies were found to be large, yellow, raised and mucoid having a diameter of 3-4 mm on the TCBS agar plates. Isolates that showed typical biochemical features of $V$. alginolyticus were further found to exhibit growth ability at $40{ }^{\circ} \mathrm{C}$. Positive reactions for oxidase test, citrate utilization test, Voges-proskauer test, lysine and ornithine decarboxylases growth at $40^{\circ} \mathrm{C}$, nitrate reduction, swarming motility, alkaline red slant and acidic yellow butt in KIA test, indole production, motility, salt tolerance test and gave negative reaction to methyl red test, were identified as $V$. alginolyticus ${ }^{19}$. All the strains were sensitive to $150 \mu \mathrm{g}$ vibrio-static 0/129 compound (2, 4-diamino-6, 7diisopropylpteridine phosphate) but resistant to the concentration of 10 which is another unique feature of V. alginolyticus. Results of the biochemical tests are shown in Table 2.

Table 1. Locations of different sampling sites of Vibrio alginolyticus

\begin{tabular}{|c|c|c|c|c|c|}
\hline \multirow[t]{2}{*}{ Collection Period } & \multirow[t]{2}{*}{ Area of Sample Isolation } & \multicolumn{2}{|c|}{ Temperature $\left({ }^{\circ} \mathrm{C}\right)$} & \multirow[t]{2}{*}{ Salinity (\%) } & \multirow[t]{2}{*}{ No. of positives } \\
\hline & & Air & Water & & \\
\hline June, 2008 & Estuary (Chittagong) & 32 & 24 & 0.9 & 6 \\
\hline June, 2008 & Kornaphuli(Chittagong) & 31 & 25 & 0.1 & 3 \\
\hline June, 2008 & Sangu (Chittagong) & 34 & 25 & 0.1 & 4 \\
\hline June, 2008 & Buriganga (Dhaka) & 30 & 23 & 0 & 0 \\
\hline June, 2008 & Turag (Dhaka) & 32 & 24 & 0 & 1 \\
\hline June, 2008 & SitaLakhya (Narayanganj) & 32 & 22 & 0 & 4 \\
\hline June, 2008 & Padma (Rajshahi) & 34 & 26 & 0 & 0 \\
\hline August, 2008 & Padma (Maoa) & 31 & 22 & 0 & 3 \\
\hline July, 2008 & Meghna( Comilla) & 30 & 22 & 0 & 4 \\
\hline June, 2008 & Jamuna (Shirajganj) & 29 & 24 & 0 & 0 \\
\hline
\end{tabular}

Table 2. Results of biochemical reactions of the Vibrio alginolyticus isolate from river and brackish water environments

\begin{tabular}{|c|c|c|c|c|c|c|c|c|c|c|}
\hline \multirow{2}{*}{$\begin{array}{l}\text { Area of isolation } \\
\text { Strain ID }\end{array}$} & \multicolumn{4}{|c|}{$\begin{array}{c}\text { Estuary } \\
\text { (Chittagong) }\end{array}$} & \multicolumn{2}{|c|}{$\begin{array}{l}\text { Shangu river } \\
\text { (Chittagong) }\end{array}$} & \multirow{2}{*}{$\begin{array}{c}\text { Sitalakhya river } \\
\text { (Narayanganj) } \\
\text { S1 }\end{array}$} & \multicolumn{3}{|c|}{$\begin{array}{l}\text { Meghna river } \\
\text { (Comilla) }\end{array}$} \\
\hline & E1 & E3 & E4 & E5 & Sg1 & Sg3 & & M1 & M2 & M3 \\
\hline Lysine & + & + & + & + & + & + & + & + & + & + \\
\hline Arginine & - & - & - & - & - & - & - & - & - & - \\
\hline Ornithine & + & + & + & + & + & $+/-$ & + & + & + & + \\
\hline Indole & + & $+/-$ & + & + & + & $+/-$ & + & + & + & + \\
\hline MR & - & - & - & - & - & - & + & - & - & - \\
\hline VP & + & + & + & + & + & + & _ & + & + & + \\
\hline KIA Slant & A & $\mathrm{K}$ & K & $\mathrm{K}$ & $\mathrm{K}$ & $\mathrm{K}$ & $\mathrm{K}$ & $\mathrm{K}$ & $\mathrm{K}$ & $\mathrm{K}$ \\
\hline Butt & A & $\mathrm{A}$ & A & $\mathrm{A}$ & A & A & A & A & A & A \\
\hline
\end{tabular}

[Keys: K=Alkaline; A=Acidic; + = Positive; - = Negative; R= Resistant; $\mathrm{S}=$ Sensitive ] 


\section{Antibiotic resistance}

All the 9 isolates were tested for their susceptibilities against the six commonly used antibiotics and were found to be susceptible to nalidixic acid, resistant to ampicillin, streptomycin and penicillin and intermediate susceptible to tetracycline. Moreover, isolates each from Meghna (M1), Estuary (E5) and Shangu river (Sg2) showed intermediate susceptible to Novobiocin. Results are shown in Table 3.

Table 3. Drug resistance pattern of $V$. alginolyticus against different antibiotics

\begin{tabular}{|c|c|c|c|c|c|c|c|}
\hline \multirow[t]{2}{*}{ Sample } & \multirow[t]{2}{*}{ Strain ID } & \multicolumn{6}{|c|}{ Susceptibility pattern } \\
\hline & & AMP & STR & NAL & NOV & PEN & TET \\
\hline \multirow[t]{3}{*}{ Meghna river } & M1 & $\mathrm{R}$ & $\mathrm{R}$ & S & I & $\mathrm{R}$ & I \\
\hline & M2 & $\mathrm{R}$ & $\mathrm{R}$ & S & $\mathrm{R}$ & $\mathrm{R}$ & I \\
\hline & M3 & $\mathrm{R}$ & $\mathrm{R}$ & S & $\mathrm{R}$ & $\mathrm{R}$ & I \\
\hline \multirow[t]{4}{*}{ Estuary } & E1 & $\mathrm{R}$ & $\mathrm{R}$ & S & S & $\mathrm{R}$ & I \\
\hline & E3 & $\mathrm{R}$ & $\mathrm{R}$ & S & $\mathrm{R}$ & $\mathrm{R}$ & I \\
\hline & E4 & $\mathrm{R}$ & $\mathrm{R}$ & S & $\mathrm{R}$ & $\mathrm{R}$ & I \\
\hline & E5 & $\mathrm{R}$ & $\mathrm{R}$ & S & I & $\mathrm{R}$ & I \\
\hline \multirow[t]{2}{*}{ Shangu river } & Sg1 & $\mathrm{R}$ & $\mathrm{R}$ & S & $\mathrm{R}$ & $\mathrm{R}$ & I \\
\hline & Sg2 & $\mathrm{R}$ & $\mathrm{R}$ & S & I & $\mathrm{R}$ & I \\
\hline
\end{tabular}

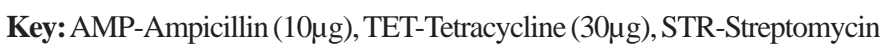

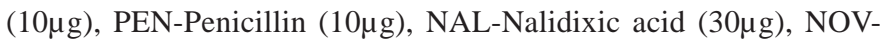
Novobiocin $(30 \mu \mathrm{g})$, R-Resistant, S-Sensitive, I-Intermediate.

\section{Hemolysis on blood agar}

A total of 7 isolates, three from river (M2, M3, and Sg1) and 4 strains of brackish water (E1, E3, E4 and E5) were tested for the hemolytic activity in the blood agar plates. After overnight incubation at $37{ }^{\circ} \mathrm{C}$, all 7 isolates of $\mathrm{V}$. alginolyticus showed the zone of $\beta$-hemolysis on blood agar.

Detection of toxR gene and tdh gene

All isolates showing positive biochemical results were also checked for the presence or absence of tox $\mathrm{R}$ gene, using tox $\mathrm{R}$ specific primers, since tox $\mathrm{R}$ gene is well conserved among Vibrio species $20,21,22$. When template DNA from each isolate was subjected to amplification through PCR, two isolates (M3 and E5) yielded DNA bands (399 bp) specific for toxR region after 35 cycles of amplification (Figure 1). V. alginolyticus isolates were further subjected to PCR using $t d h$ - specific primers as a reconfirmatory test for the presence of virulence gene $t d h$. However, all the isolates showed negative results for the presence of $t d h$ gene after 35 cycles of amplification.

\section{Challenge experiment}

Cohabitation assay: In the first round of experiments, where water of three different aquariums containing 10 fish each and inoculated with different dilutions of $V$. alginolyticus, were found to infect different organs of the fish within 5 days after inoculation. In the second round of experiments, where two infected fish (marked as smaller) from each aquarium of first round were transferred to fresh aquariums containing 10 fish

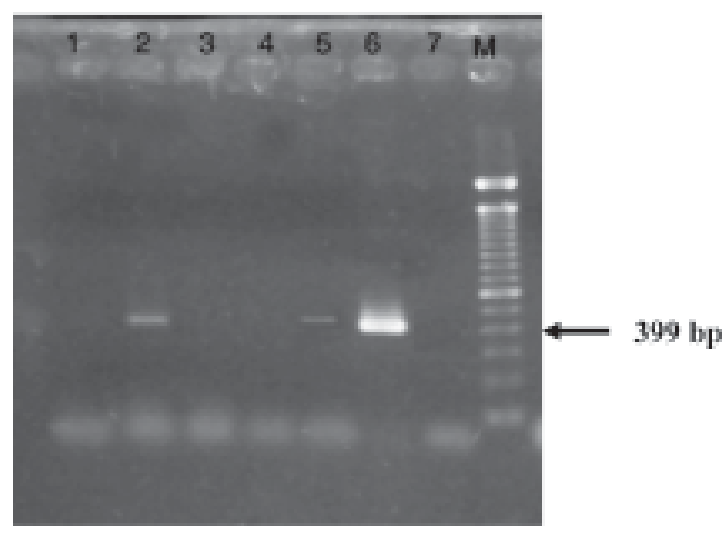

Figure 1. Agarose gel electrophoresis of the PCR product. Template DNA from $V$. alginolyticus isolates were subjected to amplification through PCR, two isolates (M3, lane 2 and E5, lane 5) yielded DNA bands of $399 \mathrm{bp}$ specific for toxR region after 35 cycles of amplification. Lane $M$ - $100 \mathrm{bp}$ molecular weight marker; Lane 7- Negative control; Lane 6Positive control strain VP11 (New clone of serotype O3:K6); Lane (1-5) - Test isolates from estuarine and river sediment sample (M2, M3. Sg1, E4, E5 respectively)

each, could infect the healthy fish (marked as longer). Different organs of the dead fish were checked for the presence of $V$. alginolyticus and it was observed that there was not much differences in the bacterial numbers in different organs of the infected fish in aquariums inoculated with different dilutions of $V$. alginolyticus organisms $(\mathrm{p}<0.05)$. All fish in the first round of experiments also died between 7 and 10 days. However, the average incidence of mortality of fish was found to be more severe in E5 series than the M3 series of $V$. alginolyticus organisms. Similar results were also obtained in the second round of experiments, where two infected fish from each of the three infected aquariums were transferred to fresh aquariums containing healthy fish. Here the average incidence of mortality of the fish was found to be $79.17 \%$ (for E5 series) and $70.83 \%$ (for M3 series), respectively, and these fish died between 8 and 14 days. Mortality of fish was more severe in E5 series than M3 series of $V$. alginolyticus organisms $(\mathrm{p}<0.05)$.

Inoculation with live cells: All fish which were inoculated intraperitoneally with live $V$. alginolyticus organisms died between two and five days after inoculation. It was noted that fish which were inoculated with E5 series organisms died earlier than the fish which were inoculated with M3 series of $V$. alginolyticus organisms. All V. alginolyticus organisms isolated from different organs of the dead or infected fish were subjected to antibiogram profile to confirm the origin of the $V$. alginolyticus.

Inoculation with culture filtrate: All fish inoculated intraperitoneally with the culture filtrate of the E5 series $V$. alginolyticus organisms died within 2 days after inoculation. On the other hand, all negative control fish without any inoculation were found healthy till the end of the experiments. 


\section{Discussion}

V. alginolyticus is a halophillic organism that normally inhabits marine and estuarine environments. This study was undertaken to isolate the $V$. alginolyticus organism, if any, in the rivers and estuaries of Bangladesh and characterize their virulence properties. Isolation and identification of the target bacterium is very crucial for its characterization and comparison and in this study, isolation required a pre-enrichment step followed by growth on selective media. According to Bergey's Manual of Systemic Bacteriology, isolates those showed positive reaction to oxidase test, citrate utilization test, acetone production, utilization of amino acids lysine, arginine and ornithinine, nitrate reduction, alkaline red slant and acidic yellow butt in KIA, positive indole production, swarming motility and tolerance up to $10 \% \mathrm{NaCl}$ were identified as V. alginolyticus.

Antibiotic susceptibility is an important parameter for the characterization of organisms and $V$. alginolyticus has been reported to be resistant to ampicillin, methicillin, lincomycin, penicillin, and carbenicillin and susceptible to tetracycline, chloramphenicol, gentamicin, kanamycin, streptomycin, and neomycin ${ }^{2,23,24}$. However, all isolates showed sensitivity to nalidixic acid.

Virulent $V$. alginolyticus possess a number of enzymes such as hemolysin, collaginase, elastase, protease, etc. that play potential role in their pathogenecity ${ }^{3,7,10}$. In this study, a total of seven isolates, three from river (M2, M3, and Sg1) and four strains from brackish water (E1, E3, E4 and E5) showed zone of áhemolysis on blood agar, indicating the production of hemolysin by these organisms. These isolates were then extensively studied for the presence of any toxin production controller gene such as tox $\mathrm{R}$ or toxin producing gene, like $t d h$ or $t r h$. All isolates showing $\beta$ haemolysis on blood agar were also observed for the presence of tox $\mathrm{R}$ gene, using tox $\mathrm{R}$ specific primers. However, none of the isolates showed positive results for the presence of $t d h$ gene, which confirmed the inability for the production of themostable direct haemolysin by the $V$. alginolyticus organisms.

In this study, the challenge experiment demonstrated that the $V$. alginolyticus organisms were found to infect different organs of the Singhi fish (Heteropneus fossilis) and all fish died between 7 and 11 days after the fish were kept in aquariums inoculated with different dilutions of the V. alginolyticus. Also, infected fish were able to cause disease in the healthy fish and the average incidence of mortality was found to be $79.2 \%$ for $V$. alginolyticus isolated from estuaries and $70.8 \%$ for $V$. alginolyticus isolated from rivers, respectively. However, in all cases, mortality was found to be more severe in $V$. alginolyticus isolated from the estuaries than the river isolates. Pathogenic nature of the $V$. alginolyticus were also revealed when live bacteria were inoculated in the fish intraperitoneally. Overall our results clearly indicate that extracellular toxin(s) might be one of the virulence factors of the $V$. alginolyticus responsible for fish mortality. Although the $V$. alginolyticus organisms were found to lack the pathogenic $t d h$ gene, however, the challenge experiments strongly demonstrate the pathogenic nature of the $V$. alginolyticus in fish model. Characterization of the extracellular toxin(s) responsible for the fish mortality could be one of the future directions in V. alginolyticus pathogenicity research.

\section{References}

1. Verschuere L, Rombaut, G, Sorgeloos P. \& Verstraete W. 2000. Probiotic bacteria as biological control agents in aquaculture. Microbiol Mol Biol Rev. 64: 655-671.

2. Joseph SW, Colwell RR \& Kaper JB. 1983. Vibrio parahaemolyticus and related halophilic vibrios. Crit. Rev. Microbiol. 10: 77-123.

3. Chien JY, Shih JT, Hsueh PR, Yang PC \& Luh KT. 2002. Vibrio alginolyticus as the cause of pleural empyma and bacteremia in an immunocompromised patient. Eur J Clin Microbiol Infect Dis. 21: 401-403.

4. Balebona MC, Andreu MJ, Bordas MA, Zorrilla I, Morinigo MA\& Borrego JJ. 1998. Pathogenecity of Vibrio alginolyticus for cultured gilt-head sea bream (Sparus aurata L.). Appl Environ Microbiol. 64: 4269-4275.

5. Gómez-León J, Villamil L, Lemos, ML, Novoa B. \& Figueras A. 2005. Isolation of Vibrio alginolyticus and Vibrio splendidus form aquacultured carpet shell clam (Ruditapes decussates) larvae associated with mass mortalities. Appl Environ. Microbiol. 71:98104.

6. Liu CH, Cheng W, Hsu JP \& Chen JC. 2004. Vibrio alginolyticus infection in the white shrimp Litopenaeus vannamei confirmed by polymerase chain reaction and 16S rDNA sequencing. Dis. Aquat. Organ. 61:169-174.

7. Xie ZY, Hu CQ, Chen C, Zhang LP, Ren CH. 2005. Investigation of seven Vibrio virulence genes among Vibrio alginolyticus and Vibrio parahaemolyticus strains from the coastal multiculture systems in Guangdong, China. Lett Appl Microbiol. 41:202-207.

8. Shinoda S, Honda T, Takeda Y \& Miwatani T. 1974. Antigenic differences between polar montrichous and peritrichous flagella of Vibrio parahaemolyticus. J. Bact. 120:923-928.

9. Grynkiewicz G, Poenie M \& Tsien RY. 1985. A new generation of $\mathrm{Ca}^{+2}$ indicators with greatly improved fluorescence properties. $J$ Biol Chem. 260: 3440-3450.

10. Barbieri E, Falzano L, Fiorentini C, Pianetti A, Baffone W, Fabbri A, Matarrese P, Casiere A, Katouli M, Kuhn I, Mollby R, Bruscolini F \& Donelli G. 1999. Occurrence, diversity, and pathogenecity of halophilic Vibrio spp. and non-01 Vibrio cholerae from estuarine waters along the Italian Adriatic coast. Appl Environ Microbiol. 65: 2748-2753.

11. Eko FO, Udo SM \& Antia-Obong OE. 1994. Epidemiology and spectrum of vibrio diarrheas in the lower cross river basin of Nigeria. Cent. Eur. J. Public Health 2: 37-41.

12. Chiou A, Chen L-H \& Chen S-K. 1991. Foodborne illness in Taiwan, 19811989. Food Aust. 43: 70-71.

13. Kim N J, Sugano Y, Hirai M \& Shoda M. 2000. Removal of a high load of ammonia gas by a marine bacterium, Vibrio alginolyticus. J Bioscience Bioengineering 90: 410-415.

14. Jayaprakash NS, Pai SS, Philip R. \& Singh IS 2006. Isolation of a pathogenic strain of Vibrio alginolyticus from necrotic larvae of Macrobrachium rosenbergii (de Man). J Fish Diseases 29: 187-191.

15. Austin B. 1992. Aeromonadaceae and Vibrionaceae. In: Identification Methods in applied and Environmental Microbiology (Society for applied bacteriology, Technical series No 29) (Ed. R.G. Board, D. Jones and F.A. Skinner), pp. 163-182. London: Academic press.

16. Cappuccino J \& Sherman N. 1996. Microbiology: A Laboratory Manual. Benjamin Cummings press, Pearson Education, $\underline{\text { San Francisco, USA. }}$ 
17. Bauer AW, Kirby MM, Sherris JC \& Truck M. Antibiotic susceptibility testing by a standardized single disk method. Am J Clin Pathol .1966. 45:493-6.

18. Boom R, Sol CJ, Salimans MM, Jansen CL, Wertheim-van Dillen PM \& van der Noordaa J. Rapid and simple method for purification of nucleic acids. $J$ Clin Microbiol. 1990. 28:495-503.

19. U.S. Food \& Drug Administration. 1969. Isolation and identification of Vibrio parahaemolyticus. Bacteriological analytical manual. U.S. Food and Drug Administration, Wshington, D.C.

20. Miller VL, Taylor RK \& Mekalanos JJ. 1987. Cholera toxin transcriptional activator ToxR is a transmembrane DNA binding protein. Cell 48: 271-279.

21. Lin Z, Kumagai K, Baba K, Mekalanos JJ \& Nishibuchi M. 1993. Vibrio parahaemolyticus has a homolog of the Vibrio cholerae toxRS operon that mediates environmentally induced regulation of the thermostable direct hemolysin. Journal of Bacteriology 175: 3844-3855.

22. Reich KA \& Schoolnik GK. 1994. The light organ symbiont Vibrio fischeri possesses a homolog of the Vibrio cholerae transmembrane transcription activator ToxR. Journal of Bacteriology 176: 3085-3088.

23. Baumann P \& Schubert RHW. 1984. Vibrionaceae. In Bergey's manual of systematic bacteriology (Krieg NR and Holt JG), $1^{\text {st }}$ edn, pp 516-538. The Williams \& Wilkins Co., Baltimore.

24. Joseph SW, DeBell RM \& Brown WP. 1978. In vitro response to chloramphenicol, tetracycline, ampicillin, gentamicin, and beta-lactamase production by halophilic vibrios from human and environmental sources. Antimicrob Agents Chemother. 13:244-248. 